\title{
Joggyakorlat
}

\author{
VIG ZOLTÁN*
}

\section{A Bécsi Vételi Egyezmény Tanácsadó Testületének a vevő megvizsgálási és értesítési kötelezettségének határidejével, az általános szerződési feltételekkel, valamint a kamattal kapcsolatos véleményei és a nemzeti bíróságok gyakorlata}

Bécsi Vételi Egyezmény - nemzetközi adásvétel - CISG - Tanácsadó Testület

A standardizációnak a gazdasági hatékonyság szempontjából egy globális világban óriási jelentősége van. Ez igaz a jogtudomány területére is, és föleg a nemzetközi kereskedelmi jogra. Ugyanakkor, nemzetközi jellege ellenére, ezen a jogterületen is meglepően kevés olyan mintatörvény vagy nemzetközi egyezmény született, amelyek megpróbálták volna egységesíteni az idevonatkozó anyagi jogot. Ezek közül a legfontosabb az Egyesült Nemzeteknek az áruk nemzetközi adásvételi szerződéseiről szóló, Bécsben, az 1980. évi április hó 11. napján kelt Egyezménye (a továbbiakban: Egyezmény), melyet Magyarországon az 1987. évi 20. törvényerejü rendelet hirdetett ki. Az Egyezményt eddig 89 állam ratifikálta, ami jelentős sikernek számít. ${ }^{1}$

A gyakorlatban a legnagyobb problémát egy ilyen jellegü egyezménynél az egyes rendelkezések egységes értelmezése és alkalmazása jelenti. Az Egyezmény 7 . cikkének (1) bekezdése foglalkozik az egységes alkalmazás követelményével, ${ }^{2}$ amit

* Dr. Víg Zoltán egyetemi adjunktus, Szegedi Tudományegyetem Állam- és Jogtudományi Kar Nemzetközi Magánjogi Tanszék. E-mail: jogasz@gmail.com.

1 2018. 11. 30-i állapot: http://www.uncitral.org/uncitral/en/uncitral_texts/sale_goods/1980CISG_status.html (2018. 11. 30.).

2 Az egységes értelmezés követelményével kapcsolatban lásd OsBORNE, Philip James: Unification or Harmonisation: A Critical Analysis of the United Nations Convention on Contracts for the International Sale of Goods 1980. 2006 (www.cisg.law.pace.edu/cisg/biblio/osborne.html\#ch4 [2018. 12. 30.]). 
némelyek úgy értelmeznek, hogy a bíróságoknak és választottbíróságoknak az Egyezmény alkalmazása során precedensként figyelembe kell venniük más nemzeti bíróságok korábbi döntéseit. ${ }^{3} \mathrm{Ez}$ az álláspont annyiban problematikus, hogy a precedensrendszer a bíróságok közötti hierarchián alapszik, és ebben az esetben az egyes nemzeti bíróságok vagy választottbíróságok között ilyen nem létezik. Sajnos a szerződést kidolgozó Nemzetközi Kereskedelmi Jogi Bizottság (UNCITRAL) nem foglalkozik az Egyezmény gyakorlati alkalmazása során felmerülö kérdések megválaszolásával. Mivel egyre több kérdés merült fel az utóbbi évtizedekben, 2001-ben magánkezdeményezésre, elismert nemzetközi szakértők, jogtudósok létrehozták az Egyezmény Tanácsadó Testületét (CISG Advisory Council). ${ }^{4}$ A Testület feladatának tekinti az Egyezmény egységes értelmezésének elősegítését, és e célból tanácsadó testületi véleményeket fogalmaz meg. A gyakorlatban ezek a vélemények elősegíthetik az Egyezmény világszerte egységes alkalmazását, habár semmiféle kötőerövel sem bírnak.

Ugyanakkor, mivel ilyen sok különböző jogrendszerben alkalmazzák, érdemes folyamatosan nyomon követni, hogy az egyes nemzeti bíróságok az Egyezmény egyes rendelkezéseit hogyan értelmezik a gyakorlatban, és hogy figyelembe veszik-e a Tanácsadó Testület véleményeit. A jogegységesítés folyamata ugyanis nem áll meg az Egyezmény elfogadásával, hanem a joggyakorlat közös mederben tartására is kiterjed, ennek pedig a legjobb módja a folyamatos „kommunikáció” biztosítása a bíróságok között, azaz az egyes nemzeti bíróságok ítéleteinek az elérhetővé tétele, elemzése. Ezt a feladatot szeretné betölteni a jelen tanulmány is, amely a különböző nemzeti bíróságoknak az utóbbi néhány évben született döntéseit, valamint az Egyezmény Tanácsadó Testületének véleményeit vizsgálja három témakörben: a vevő megvizsgálási és értesítési kötelezettségének határideje, az általános szerződési feltételek, valamint a kamat kérdése.

\section{A vevő megvizsgálási és értesítési kötelezettségének határideje}

2004-ben született meg a Tanács 2 . számú véleménye, amely a vevő megvizsgálási és értesítési kötelezettségével foglalkozik, és melynek a megszövegezésében Schlechtriem professzor is részt vett. ${ }^{5}$ Az Egyezmény megfogalmazása során ezek voltak a legtöbbet vitatott kérdések, és jelenleg is a legellentmondásosabb és legtöbb jogvita tárgyát ezek képezik, az egyes nemzeti jogokban levő eltérések miatt. Az Egyezmény megszövegezésénél a szigorú értesítési rendszerrel rendelkező

3 FerRARI, Franco: CISG Case Law: A New Challenge for Interpreters? Journal of Law and Commerce, 1999/17, 257-260.

4 CISG Advisory Council. https://www.cisgac.com (2018. 12. 28.).

5 CISG Advisory Council Opinion No. 2. http://www.cisg.law.pace.edu/cisg/CISG-AC-op2.html (2018. 12. 28.); A 2. számú véleménnyel kapcsolatos kérdések nagyszerű elemzését adja Szabó Sarolta. Lásd SzABó Sarolta: A bécsi vételi egyezmény, mint nemzetközi lingua franca. Pázmány Press, Budapest, 2014, 109-129. 
fejlett országok kerekedtek felül, ${ }^{6}$ de azért, hogy a fejlődő országoknak is kedvezzenek, bekerült az egyezménybe a 44. cikk, amely kimondja, hogy ha a vevőnek észszerủ mentsége van a megkívánt értesítés elmulasztására, úgy - a 39. cikk (1) és a 43. cikk (1) bekezdések rendelkezéseitől függetlenül - az 50. cikknek megfelelően csökkentheti a vételárat, vagy követelheti az elmaradt hasznok nélküli, tényleges kárának megtérítését. Ami a vevő megvizsgálási és értesítési kötelezettségének határidejét illeti, a vélemény kiemeli, hogy az értesítési idő két külön időszakból áll: az első a 38. cikk szerinti megvizsgálási idő, míg a másik a 39. cikk szerinti értesítési (kifogásolási) idő. Ez alól természetesen kivételt jelent, ha nyilvánvalóan hibás az áru. A 38. cikk szerint a vevő a körülmények által lehetővé tett legrövidebb időn belül meg kell hogy vizsgálja az árut. Ennek természetesen feltétele, hogy az áru már a rendelkezésére álljon. A megvizsgálási idő számításának is ez a kezdő időpontja. A vélemény kihangsúlyozza, hogy ilyenkor az eset minden körülményét figyelembe kell venni (például az áru fajtáját, a technikai lehetőségeket). ${ }^{7}$ Így romlandó áru esetén ez rendszerint az áru átvételének az ideje, esetleg néhány nap, míg tartós használati cikkek esetén, mint amilyenek a gépek, ez addig nem várható el, amíg azokat üzembe nem helyezik, kivéve a külsőleg is látható hibákat. Rejtett hibák esetén ez még hosszabb idő is lehet a vélemény szerint, éspedig amíg a hiba nem válik nyilvánvalóvá. ${ }^{8}$ A 39. cikk az eladónak a hibáról történő értesítéséről rendelkezik. Ez az idő a hiba vevő általi felfedezésével kezdődik, illetve objektíve azzal az időponttal, amikor azt fel kellett volna fedeznie. A vélemény szerint a cikkben írt „ésszerủ időt” nem lehet meghatározni, az olyan körülményektöl függ, mint az áru jellege, a hiba természete, a felek helyzete, vagy az alkalmazandó kereskedelmi szokások. A vélemény szintén megemlíti (annak ellenére, hogy a 39. cikk megköveteli a hiba megjelölését), hogy bizonyos esetekben elég csak a hiba jellegét közölni (pl. komplikált gépeknél).

${ }^{6}$ Az Egyezmény 38. cikke:

(1) A vevő a körülmények által lehetővé tett legrövidebb időn belül köteles az árut megvizsgálni vagy megvizsgáltatni.

(2) Ha a szerződés kiterjed az áru elfuvarozására is, a vizsgálat az árunak a rendeltetési helyre való megérkezését követő időpontra halasztható.

(3) Ha az úton levő árut átirányítja vagy anélkül továbbküldi, hogy ténylegesen lehetősége volna annak megvizsgálására és a szerződéskötés időpontjában az eladó tudott vagy tudnia kellett az átirányítás, illetve továbbküldés lehetőségéről, a vizsgálat mindaddig elhalasztható, míg az áru új rendeltetési helyére megérkezik.

Egyezmény 39. cikke:

(1) A vevő elveszti azt a jogát, hogy az áru minőségi hibájára hivatkozzék, ha erről az eladót a hiba megjelölésével, ésszerủ időn belül nem értesíti, azt követően, hogy a hibát felfedezte, vagy azt fel kellett volna fedeznie.

(2) A vevő minden esetben elveszti az áru minőségi hibájára való hivatkozás jogát, ha legkésőbb az áru átadásától számított két éven belül a hibát az eladóval nem közölte, hacsak ez a határidő nem ellentétes a szerződéses jótállás határidejével.

7 Ezzel kapcsolatban lásd FerRaRI, Franco: Divergences in the application of the CISG's rules on non-conformity of goods. Rabels Zeitschrift für ausländisches und internationales Privatrecht, 2004/július, 282.

8 SÁnDor Tamás-VÉKÁs Lajos: Nemzetközi adásvétel. HVG-ORAC, Budapest, 2005, 226. 
Szabó rámutat, hogy sajnos az egyes nemzeti bíróságok gyakorlata meglehetősen eltérő a megvizsgálási határidővel kapcsolatban (például a német, osztrák, svájci bíróságok sokkal szigorúbbak). ${ }^{9}$

Egy az Arnhemi Fellebbviteli Bíróság (Gerechtshof Arnhem) elötti perben a központi kérdés épp az volt, hogy a vevő értesítése az Egyezmény 39. cikk (1) bekezdésének értelmében észszerü időn belül történt-e. ${ }^{10} \mathrm{Az}$ eladó egy holland, a vevő pedig egy belga telephellyel rendelkező cég volt. 2003. február 17. óta az eladó tésztakészételek előállításához szállított alapanyagot a vevőnek. 2003. április 28-án a vevő kapott egy korai panaszt az alapanyag egyik megvásárlójától, de 2003. július 4-ig várt, mielőtt értesítette volna a termékek hibás jellegéről az eladót. A vevő véleménye szerint az értesítés időben el lett küldve, mert a szakértői vizsgálat 2003. július 1-én fejeződött be (továbbá az áru minőségével kapcsolatban már korábban kapcsolatba lépett az eladóval). ${ }^{11}$ Az elsőfokú bíróság úgy ítélte meg, hogy ha romlandó áruról van szó, a szerződésszerüség vizsgálatának akkor kell megtörténnie, amikor a veszély átszáll a vevőre [36. cikk (1) bekezdése], és ennek a vizsgálatnak késedelem nélkül kell megtörténnie. Ennélfogva a vevőnek csak egy rövidebb időtartam áll rendelkezésére, hogy értesítse az eladót a szerződésszerűség hiányáról, hogy ez észszerü időben történő értesítésnek számítson a 39. cikk (1) bekezdése alapján. Ebben az esetben romlandó áruról volt szó, tehát haladék nélküli [azaz, ahogy az Egyezmény 38. cikk (1) bekezdése fogalmaz: a körülmények által lehetővé tett legrövidebb időn belüli] vizsgálatra lett volna szükség, mivel az alapanyag minőségének vizsgálata a feldolgozást követően lehetetlen vállalkozás. ${ }^{12}$ Ezt a döntést megfellebbezte a vevő. Mivel a fellebbviteli bíróság csak egy függő hatályú döntést hozott, nem történt végleges állásfoglalás a részéről. Ugyanakkor alapvetően az eladói nézőpont felé hajlott, tehát véleménye szerint is a megvizsgálás nem történt meg észszerü időn belül, azaz a körülmények által lehetővé tett legrövidebb időn belül, és ezt követően pedig egy szintén észszerű időn belüli értesítésre lett volna szükség a 39. cikk (1) bekezdése alapján.

Egy másik érdekes eset a 2. számú vélemény vonatkozásában a Szöuli Központi Kerületi Bíróság egyik ítélete, 2013-ból. ${ }^{13}$ Ebben az ügyben a vevő sertés mellső lábakat szerzett be az eladótól. A probléma abból adódott, hogy az áru hibás volt, ugyanis az eladó nem távolította el, illetve helytelenül távolította el a nyirokcsomókat a mellső lábakból, ami a hús elszíneződéséhez vezetett. Ez azért érdekes, mert ugyan a Tanácsadó Testület külön kiemeli, hogy rendes körülmények között, romlandó áru esetében a vevői vizsgálat az áru átvételekor kell hogy megtörténjen, de itt felmerül a rejtett hiba lehetősége. Ugyanis a disznóhús esetében a nyirokcsomók jelenléte nem könnyedén azonosítható (például a nyers marhahús jellegzetes elszí-

9 SzABÓ: i. m., 111.

10 Gerechtshof Arnhem 2010. március 9-én hozott ítélete. http://cisgw3.law.pace.edu/cases/100309n1.html (2018. 12. 29.).

11 Gerechtshof Arnhem 2010. március 9-én hozott ítélete, 3. pont. http://cisgw3.law.pace.edu/cases/100309n1. html (2018. 12. 29.).

12 Gerechtshof Arnhem 2010. március 9-én hozott ítélete, 4.8. pont. http://cisgw3.law.pace.edu/cases/ 100309n1.html (2018. 12. 29.).

13 Clout case 1641. http://www.uncitral.org/clout/clout/data/kor/clout_case_1641_291113.html (2018. 12. 29.). 
neződésével ellentétben), a hiba sokszor csak a hús megsütésekor derül ki, és az elszíneződés mértéke a hőfoktól is erősen függ. Tehát az átvételkori szokásos érzékszervi megvizsgálás a legtöbb esetben elégtelen arra, hogy kiszűrje ezt a hibát. ${ }^{14}$ Továbbá a megvizsgálás során a megsütés az áru egy részének „megsemmisítésével" is együtt járna, $s$ ráadásul azt többféle hőfokokon is el kellene végezni, tehát ez már az elvárhatóság határát is súrolná. Ez a szituáció tipikus példa arra, hogy romlandó áruk esetében is jelentkezhetnek olyan rejtett hibák, amelyek nem könynyedén azonosíthatók az áru átvételekor. A Tanácsadó Testület véleménye szerint rejtett hiba esetén a megvizsgálási időtartam akkor kezdődik, amikor a hiba jelei nyilvánvalóvá válnak. Ugyanakkor a szöuli bíróság ezt teljesen figyelmen kívül hagyta, mivel pusztán arra alapozta ítéletét, hogy tíz hónappal az átvétel után történt meg az értesítés (ráadásul nem is vizsgálta külön a Tanácsadó Testület által elhatárolt vizsgálati és értesítési időt), és úgy döntött, hogy a vevő észszerü időn belül nem értesítette az eladót a hibáról, tehát elvesztette az ezzel kapcsolatos jogait. A bíróságnak figyelembe kellett volna vennie, hogy rejtett hibáról van szó, valamint, hogy a vevő hogyan kívánta felhasználni az árut (például ha az átvétel és a romlottsági vizsgálat után rögtön mélyfagyasztásra kerülnek a mellső lábak, a nyirokcsomókból eredő hiba potenciálisan csak hónapokkal később derülhet ki).

A 2. számú vélemény kapcsán még egy újabb, orosz ügyet érdemes megemlíteni, melynek elbírálása az orosz Északnyugati Körzet Kereskedelmi Bírósága előtt zajlott. ${ }^{15}$ Ebben az esetben egy német eladó adott el orosz vevőnek félkész élelmiszereket. Ezek az áruk az átvételt követően azonnal eladásra kerültek egy harmadik félnek, akinél kiderült az áru hibás természete. Ez alapján a vevő megtagadta a fizetést, akit ezt követően az eladó beperelt. Az ügy eljutott másodfokra és harmadfokra is, de mindhárom bíróság azonos véleményen volt az esettel kapcsolatban. A felek szerződésben kikötötték, hogy az átvételtöl számított 20 napon belül kell az eladót értesíteni hibás teljesítés esetén. Ez alapján a bíróság úgy találta, hogy nem történt meg az észszerủ időn belüli értesítés. Ezenkívül még két dolgot érdemes megemlíteni a bírósági ítéletből. A bíróság megállapította, hogy a vizsgálat elvégzéséhez bizonyos feltételeknek teljesülnie kell, például az eladó bevonása a vizsgálatokba, amit a vevő, illetve a harmadik fél elmulasztott ebben az esetben. A bíróság szintén megállapította, hogy a vevőnek kellett volna elvégeznie a vizsgálatot, és mivel az árut azonnal továbbadta a harmadik félnek, ezáltal az ezzel kapcsolatos jogait is elvesztette. Ez szembehelyezkedik a 2. számú vélemény álláspontjával, mivel abban a Tanácsadó Testület konkrét példaként hozta fel, hogy továbbadott áruk esetében gyakran a harmadik fél, a végfelhasználó fogja a vizsgálatot elvégezni, és ezt az értelmező bíróságnak figyelembe kell venniük, mint az eset egyik körülményét. Itt ez értelemszerüen nem történt meg. Tehát elmondható, hogy még a legújabb ügyek esetében sem sikerült teljesen elérni azt, hogy a Tanácsadó Testület álláspontját kövessék az Egyezmény értelmezése kapcsán a nemzeti bíróságok.

\footnotetext{
14 Hunt, Melvin-Zenger, Becky: Cooked Color in Pork. National Pork Board/American Meat Science Association Fact Sheet, 2010. https://articles.extension.org/pages/27350/cooked-color-in-pork (2018. 12. 29.).

15 Clout case 1647. http://www.uncitral.org/clout/clout/data/rus/clout_case_1647_031016.html (2018. 12. 29.).
} 


\section{2. Általános szerződési feltételek}

2013-ban született meg az Egyezmény Tanácsadó Testületének 13. számú véleménye, amely az általános szerződési feltételek kérdésével foglalkozik. Az Egyezménnyel kapcsolatos esetjogot vizsgálva a vélemény leszögezi, hogy ez a kérdés kifejezetten az Egyezmény hatálya alá tartozik, annak ellenére, hogy nincs kifejezetten szabályozva. Így a vitás kérdések eldöntésénél elsősorban az Egyezmény azon szakaszaira kell támaszkodni, amelyek a szerződés megkötésével és értelmezésével foglalkoznak, ezek közül is a 8 . cikk (2) bekezdése a legfontosabb, amely kimondja, hogy a fél nyilatkozatát úgy kell értelmezni, ahogy azt a másik félhez hasonló, észszerủen gondolkodó személy azonos körülmények között értette volna. ${ }^{16}$ Ennek megfelelően a vélemény 2. pontja kimondja, hogy az általános szerződési feltételek a szerződés részét képezik, amennyiben a felek kifejezetten vagy hallgatólagosan hozzájárultak, hogy ezek a feltételek a szerződés részét képezzék a szerződés megkötésének időpontjában, valamint a másik félnek megvolt az észszerü lehetősége (reasonable opportunity), hogy azokat megismerje. ${ }^{17}$

A vélemény megalkotásának évében született meg a Naumburgi Fellebbviteli Bíróság (Németország) ítélete, egy svájci eladót és német vevőt érintő ügyben, ahol a bíróságnak többek között azt kellett eldöntenie, hogy az eladó általános szerződési feltételei a szerződés részét képezik-e. ${ }^{18} \mathrm{~A}$ felek adásvételi szerződést kötöttek $22,5 \mathrm{t}$ szemes mák adásvételére. A vevő és társa egy péküzletet üzemeltetett, míg az eladó szárított trópusi gyümölcsök importálására és exportálására szakosodott, különös tekintettel a szemes mákra. A felek e-mailes kommunikációjának következtében létrejött az adásvételi szerződés, majd az eladó elküldte a megrendelt mákot a vevőnek. A kezdeti pozitív eredményű vizsgálat és némi felhasználás után kiderült, hogy a pékség termékei a mák erős íze és szaga miatt alkalmatlanok a forgalmazásra. Ez vezetett a jogvitához. Az elsőfokú bíróság hozott egy ítéletet, de nem vette figyelembe az Egyezmény alkalmazhatóságát. Ez orvoslásra került másodfokon, ahol a bíróság kimondta, hogy az Egyezmény az alkalmazandó jog. Az eladó arra hivatkozott, hogy az általános szerződési feltételei az e-mailben létrejött szerződés részét képezik, habár erre külön nem történt utalás. Mivel a belföldi anyagi jog rendelkezéseit nem lehetett alkalmazni, illetve az Egyezmény nem tartalmaz külön rendelkezéseket az általános szerződési feltételekről, ezért a bíróság meglátása szerint szükséges volt alkalmazni az Egyezmény 8. cikkét annak eldöntésére, hogy az általános szerződési feltételek a szerződés részének tekintendők-e. A bíróság megvizsgálta az európai legfelsőbb bíróságok és a német bíróságok gyakorlatát, és arra a következtetésre jutott, hogy egyetért azok joggyakorlatával. Ennek megfelelően a bíróság megállapította, hogy az általános szerződési feltételek csak akkor képezik a szerződés

16 CISG Advisory Council Opinion No. 13. http://www.cisg.law.pace.edu/cisg/CISG-AC-op13.html (2018. 12. 29.).

17 Ezzel kapcsolatban lásd még. WANG, Faye Fangfei: The incorporation of terms into commercial contracts: a reassessment in the digital age. Journal of Business Law, 2015, 87-90. https://bura.brunel.ac.uk/ bitstream/2438/11004/1/Fulltext.pdf (2018. 12. 30.); EISELEN, Sieg: The requirement for the inclusion of standard terms in international sales contract. Potchefstroom Electronic Law Journal, 2011/14, 234-236.

18 A Naumburgi Fellebbviteli Bíróság (OLG Naumburg) 2013. február 13-án hozott ítélete. http://cisgw3.law. pace.edu/cases/130213g1.html (2018. 12. 29.). 
részét, ha a fogadó félnek megvolt a lehetősége, hogy azokat megismerje, valamint ha egyértelmüen tudomására jutott az eladó azon szándéka, hogy ezek a feltételek a szerződés részét képezik. Tehát az ajánlattevőnek el kellett volna küldenie az általános szerződési feltételeit tartalmazó szöveget, vagy azt egyéb formában (pl. a megfelelő weboldalt belinkelve) elérhetővé kellett volna tennie az ajánlatot fogadó fél részére, és hivatkozni rá, hogy az a szerződés részét képezze. Ennélfogva a vevő tájékozódási kötelezettségén túlterjed a megismerési lehetőség biztosításának feltétele. Ugyanakkor a bíróság úgy döntött, hogy nem tudja megítélni az esetet új bizonyítékok és tanúmeghallgatások nélkül. (Az ügy további sorsa nem ismert, mivel az eset visszakerült az elsőfokú bírósághoz.)

A Hágai Fellebbviteli Bíróság (Gerechtshof Den Haag) előtti ügyben szintén az általános szerződési feltételek alkalmazhatósága merült fel egy német csokoládégyártó cég mint vevő és egy holland, magok és szárított gyümölcsök kereskedelmével foglalkozó cég mint eladó vitája kapcsán. ${ }^{19} 2011$ februárjában a felek kötöttek egy szerződést, ami alapján az eladó 12000 almakarikát kellett volna, hogy leszállítson a vevőnek. A szerződésre alkalmazandó jog az Egyezmény volt. 2011. szeptember 5-én a vevő panasszal élt, arra hivatkozva, hogy az almakarikák egy része élősködőket tartalmaz, így emberi fogyasztásra alkalmatlan. E szerződést megelőzően a felek hét hasonló szerződést kötöttek, a legkorábbit 2007-ben. Ezekben a szerződésekben az eladó mindig a Holland Szárított Gyümölcs, Füszer és Kapcsolódó Termékek Kereskedelmi Társasága (NZV) általános feltételeire hivatkozott. A szerződéssel kapcsolatos minden dokumentáció angol nyelvű volt. Született egy dokumentum a legutóbbi szerződés jóváhagyásáról is, amiben az eladó tájékoztatta a vevőt, hogy a feltételek megegyeznek az NZV általános feltételeivel, melyeket az eladó irodájában megtekinthetnek, illetve kérésre azokat megküldik a vevőnek. Az első perben a vevő azt állította, hogy az eladó felelős 250000 eurónyi (plusz kamat) kárért, azáltal, hogy a leszállított almakarikák részben fertőzöttek voltak. A vevő biztosítója részben megtérítette a kárt (ezt a vevő nem számolta bele a 250000 euróba). Ugyanakkor a kifizetett 107440 eurós kártérítés miatt a vevő biztosítója azt állította, hogy megszerezte a követelés egy részét, és ezt az összeget (plusz kamatot) követelte az eladótól. ${ }^{20} \mathrm{Az}$ eladó arra hivatkozott, hogy a bíróságnak nincs joghatósága. Az eladó szerint ugyanis az NZV általános feltételeit kell alkalmazni a szerződésre, és mivel a feltételek tartalmaznak egy választottbírósági klauzulát, ennélfogva a felek hallgatólagosan megállapodtak a választottbíráskodásban. Ezzel egyetértett a bíróság, és megállapította a saját joghatóságának hiányát. Ezt a vevő és a biztosító is vitatta, ezért fellebbeztek. A fellebbviteli bíróság megvizsgálta az Egyezmény 7. cikkét, amely kimondja, hogy az Egyezmény értelmezése során figyelembe kell venni annak nemzetközi jellegét és annak szükségességét, hogy elősegítsék az Egyezmény egységes alkalmazását. Mivel nincs egy nemzetközi bíróság, amelynek joggyakorlata az egységes értelmezésnél irányadó lenne, a bíró-

19 Gerechtshof Den Haag 2014. április 22-én hozott ítélete. http://cisgw3.law.pace.edu/cases/140422n1.html (2018. 12. 29.).

20 Gerechtshof Den Haag 2014. április 22-én hozott ítélete, 2. pont. http://cisgw3.law.pace.edu/cases/140422n1. html (2018. 12. 29.). 
ság más országok Egyezménnyel kapcsolatos joggyakorlatát vizsgálta, valamint a fent említett Tanácsadó Testület véleményeit. ${ }^{21}$ Ezek alapján a bíróság visszautalta az ügyet az elsőfokú bírósághoz. Véleményünk szerint a fellebbviteli bíróság helyesen állapította meg, hogy az értelmezés során más nemzeti bíróságok joggyakorlatát, valamint a Tanácsadó Testület véleményeit kell vizsgálni.

A harmadik érdekes eset, amit érdemes megemlíteni a 13. számú véleményhez kapcsolódóan, az a Nucap Indus. Inc. v. Robert Bosch LLC ügy, amely jelenleg egy illinoisi bíróság elött zajlik az Egyesült Államokban. ${ }^{22}$ Ebben az ügyben egy kanadai eladó és egy illinoisi vevő került vitába egymással, fékalkatrészek adásvétele kapcsán. Az eladó (Nucap) kapcsán ki kell emelni, hogy digitális alkatrész-adatbázist épített ki az évek alatt, amihez bizonyos klienseinek exkluzív hozzáférést biztosított. Ehhez az adatbázishoz részben a vevő is hozzáfért a felek üzleti viszonyának fennállása során. Ebben az üzleti viszonyban a vevő több ezer megrendelést küldött az eladónak. Különösen fontos kiemelni, hogy 2010-töl kezdődően (a felek viszonya 2014-ben ért véget) 8000 olyan megrendelést küldött a vevő az eladónak, ami tartalmazta a vevő cégének általános szerződési feltételeit, pontosabban az arra való utalást. A felek közötti konkrét vita abból adódott, hogy a kapcsolatuk megromlása után a vevő alternatív fékalkatrész-eladókat kezdett el keresni, és ezzel kapcsolatban, összehasonlítás céljából felhasználta az eladó adatbázisából kinyert tervrajzokat. Az eladó véleménye szerint ez üzleti titoknak minősül, míg a vevő ragaszkodott hozzá, hogy az általános szerződési feltételeiből eredően erre jogosult. Az ügy kapcsán a bíróság megállapította az Egyezmény alkalmazhatóságát, így felmerült a kérdés, hogy az általános szerződési feltételeket a szerződés részének kell-e tekinteni, a fenti bekezdésekben meghatározott szempontok alapján. Mint már szó volt róla, a vevő nyolcezer megrendelésében közvetetten hivatkozott az általános szerződési feltételeire, de az eladó tagadta a bíróság előtt, hogy ezekről tudott volna. Érdekes, hogy érvelésében az eladó konkrétan hivatkozott a 13. számú véleményre, pontosabban annak 7 . pontjára, ${ }^{23}$ és azzal érvelt, hogy az általános szerződési feltételek vitatott elemei meglepőnek/szokatlannak minősülnek, és ezért nem képezik részét a szerződésnek. A bíróság úgy nyilatkozott, hogy a precedensek hiányában nem tudja megállapítani, hogy a feltételek meglepőnek/szokatlannak minősülnek-e, de mivel az eladó számára elérhetőek voltak a vevő általános szerződési feltételei a nyolcezer megrendelésben, melyek mind teljesítésre kerültek, és mivel az eladó egy „szofisztikált” fél volt (itt feltehetően arra gondolt a bíróság, hogy az eladónak mint gazdasági szereplőnek, megvoltak a kellő erőforrásai és lehetőségei az általános szerződési feltételek megismeréséhez), így elvárható lett volna tőle az általános szerződési feltételek tartalmának megismerése. ${ }^{24}$

21 Gerechtshof Den Haag 2014. április 22-én hozott ítélete, 12. pont.

22 United States District Court for the Northern District of Illinois Eastern Division, Case No. 15 C 2207, Nucap Indus. Inc. v. Robert Bosch LLC ügyben 2017. március 31-én hozott határozata. http://www.cisg-online.ch/ content/api/cisg/urteile/2827.pdf (2018. 12. 29.).

${ }^{23}$ A 7. pont szerint: „Azok az általános szerződési feltételek, amelyek annyira meglepőek vagy szokatlanok, hogy egy ésszerủen gondolkodó hasonló személy ésszerủen nem számított volna ilyen feltételekre, nem részei a szerződésnek."

24 United States District Court for the Northern District of Illinois Eastern Division, Case No. 15 C 2207, Nucap Indus. Inc. v. Robert Bosch LLC ügyben 2017. március 31-én hozott határozata. https://casetext.com/case/ nucap-indus-inc-v-robert-bosch-llc-1 (2018. 12. 29.). 


\section{Kamatfizetési kötelezettség}

A Tanácsadó Testület 14 . számú véleménye a kamat kérdésével foglalkozik. ${ }^{25}$ A vélemény szerint, habár általában a hitelező két okból jogosult kamatra; egyrészt, mert nem használhatja a pénzét (azaz feltételezik, hogy a hitelező azt befektetné és kamatoztatná, ha nála lenne), másrészt pedig, hogy ezzel is megakadályozzák az adós jogalap nélküli gazdagodását (azazhogy jogtalanul "gyümölcsöztesse” a nála levő pénzt); a 78. cikk esetében elsősorban arról van szó, hogy a 74. cikkel együtt az Egyezmény teljes kártalanítást szeretne nyújtani a károsult félnek. ${ }^{26} \mathrm{~A}$ vélemény 3. pontja meghatározza, hogy a fél mikor kerül hátralékba a fizetést illetően. Az egyik ilyen eset, amikor a vételár kifizetésének már meg kellett volna történnie. Amenynyiben a felek a pontos időpontban nem egyeztek meg, akkor az Egyezmény 58. cikke alapján lehet meghatározni a fizetés teljesítésének időpontját. Egy másik eset, amikor a kárért való felelősség felmerül, valamint amikor a visszatérítésnek már meg kellett volna történnie (esedékesség). A kamattal kapcsolatban még megjegyzi a vélemény, hogy nincs szükség külön felszólításra a kamatfizetéssel kapcsolatban, ami fontos, mivel sok nemzeti jogrendszerben ez szükséges. ${ }^{27} \mathrm{~A}$ vélemény még kiemeli a kamat kapcsán, hogy a legnagyobb problémát a jogegységesítés tekintetében a kamat mértéke jelenti. Ezzel összefüggésben a vélemény 8. pontja megállapítja, hogy a felek szabadon megegyezhetnek a kamat mértékében. A következő pont pedig kimondja, hogy amennyiben a felek ebben nem egyeztek meg, a kamat mértéke az lesz, amit a hitelező telephelye szerinti bíróság alkalmazna egy hasonló adásvételnél. ${ }^{28}$ Ennek az az indoka, hogy a hitelező feltételezhetően a saját telephelye szerinti országban fektetné be a pénzét. ${ }^{29}$

A szerb Fellebbviteli Kereskedelmi Bíróság még a fenti vélemény megszületése előtt kellett, hogy értelmezze az Egyezmény 78 . cikkét. ${ }^{30}$ Ebben az ügyben egy szerb eladó és egy bosznia-hercegovinai vevő közötti nemzetközi kereskedelmi ügyletről volt szó. Az eladó kötelezte magát, hogy 7000 eurós áron leszállít a vevőnek egy (hőpapír előállítására szolgáló) gépet 30 napon belül, amely időszak 2008.

${ }_{25}$ CISG Advisory Council Opinion No. 14. http://www.cisg.law.pace.edu/cisg/CISG-AC-op14.html (2018. 12. 29.).

26 CISG Advisory Council Opinion No. 14., 3.3.-3.7. pontok.

27 CISG Advisory Council Opinion No. 14., 3.19. pont.

${ }^{28}$ Korábban a szakirodalomban a kamat mértékének megállapítása kapcsán több különböző vélemény is létezett. Schlechtriem professzor korábban azon a véleményen volt, hogy a kollíziós jog által meghatározott nemzeti jog szabályait kell erre alkalmazni. Ziegel és Samson szerint nem egyértelmü, hogy a nemzetközi magánjog szabályai alapján kell megállapítani ebben az esetben az alkalmazandó szabályokat. A legrészletesebb elemzést Honnold adta, aki szerint ilyen esetben négy lehetőség merülhet fel: (1) a kollíziós jog által megállapított nemzeti jog által megállapított mértékủ kamat, (2) a hitelező nemzeti joga által megállapított mértékủ kamat, (3) a nemzetközi szokások alapján megállapított mértékủ kamat, (4) a sérelmet szenvedő fél hitelköltsége. SCHLECHTRIEM, Peter: Uniform Sales Law: The UN-Convention on Contracts for the International Sale of Goods. Manz, Bécs, 1986, 99; Ziegel, Jacob S.-SAmson, Claude: Report to the Uniform Law Conference of Canada on the Convention on Contracts for the International Sale of Goods. 1981, 78. cikk; Honnold, John O.: Uniform Law for International Sales Under the 1980 United Nations Convention. Kluwer Law International, Hága, 1999, 469-470.

29 CISG Advisory Council Opinion No. 14., 3.36. pont; lásd még MoLnÁR István János: A nemzetközi gazdasági kapcsolatok joga II. Patrocinium, Budapest, 2016, 80.

30 Fellebbviteli Kereskedelmi Bíróság 2011. július 6-án hozott ítélete. http://cisgw3.law.pace.edu/cases/ 110706sb.html (2018. 12. 29.). 
június 27-ével kezdődött. A vevő ezen az alapon két részletben kifizette a vételárat, a második részlet 2008. augusztus 19-én került sorra. 2008. október 8-án a vevő felszólította az eladót, hogy szállítsa le a gépet, amilyen hamar csak lehet, vagy fizesse vissza az árát, mivel már több mint három hónapos késésben volt az eladó. Az eladó ennek nem tett eleget, és a kereset benyújtásáig nem szolgáltatta a gépet a vevőnek, és nem nyújtott be bizonyítékot arra nézve sem, hogy a vételárat visszafizette volna. Ennek következtében a vevő elállt a szerződéstöl, és a keresetében a vételár visszafizetését, illetve a törvényes kamatot (2008. október 8-ától kezdődően) követelte. Az elsőfokú bíróság megállapította, hogy az Egyezményt kell alkalmazni, és hogy a vevő követelései a szerződéstől való elállás következtében, megalapozottak. A döntést az eladó megfellebbezte, a fellebbviteli bíróság azonban egyetértett ezzel a döntéssel. Ugyanakkor úgy ítélte meg, hogy az elsőfokú bíróság hibázott abban a kérdésben, hogy a vevő jogosult-e kamatra az Egyezmény 78. cikke alapján. A fellebbviteli bíróság érvelése szerint az Egyezmény 81. cikk (1) bekezdése kimondja, hogy az elállás mindkét felet mentesíti a szerződés alapján őket terhelő kötelezettségek alól, kivéve a bármely kár megtérítésére irányuló kötelezettséget. A szerződés megszünése nem érinti sem a szerződésnek a viták rendezésére vonatkozó bármely rendelkezését, sem pedig azokat a rendelkezéseit, amelyek a feleket a megszűnés folytán megillető jogokat és őket terhelő kötelezettségeket szabályozzák. A következő szakasz pedig kimondja, hogy a szerződést teljes mértékben vagy részben teljesítő fél a másik féltől mindazt visszakövetelheti, amit a szerződés alapján szállított vagy fizetett. Ha mindkét fél visszatérítésre köteles, azokat egyidejüleg kell teljesíteniük. Ebben az esetben az eladónak kellett a teljes vételárat visszaszolgáltatnia. A 84. cikk (1) bekezdése alapján pedig, ha az eladó a vételár visszatérítésére köteles, úgy annak a vételár megfizetése napjától számított kamatát is köteles megfizetni. Ugyanakkor a vevő csak 2008. október 8-ától kérte a kamatot, a bíróság pedig a kereseti kérelemnél többet nem ítélhet meg. Ennélfogva a fellebbviteli bíróság részben megváltoztatta az elsőfokú bíróság döntését, és előírta a törvényes kamat kifizetését, de csak a 2008. október 8. és 2010. március 24 . közötti időszakra vonatkozóan.

2016-ban pedig egy spanyol esetben értelmezték érdekesen a kamatfizetési kötelezettség kezdő időpontját, ami nem teljesen egyezik a 14. számú vélemény álláspontjával. Ez az ügy a Gironai Tartományi Fellebbviteli Bíróság elött került elbírálásra, spanyol vevő és görög eladó vonatkozásában. ${ }^{31} \mathrm{~A}$ felek élő kagylók adásvételéről állapodtak meg, s vita támadt közöttük hibás teljesítés kapcsán. A vevő azonban a hibás teljesítést nem tudta bebizonyítani, mivel csak egy héttel az adásvétel után végezte el a vizsgálatait, amikorra a kagylók már elpusztultak, így utólag nem lehetett megállapítani, hogy átvételkor milyen volt az élő kagylók állapota. Emiatt a vevő elvesztette az ügyet elsőfokon és másodfokon is. Az elsőfokú bíróság ugyan a 78. cikkre hivatkozva kiszabott kamatot a vevőre, de nem követte a 14. számú vélemény álláspontját, és ehelyett a kérelem benyújtásának időpontját jelölte meg a kamatszámítás kezdetének (2013. február 22.). A másodfokú bíróság ugyanakkor, figyelembe véve a teljes kártalanítás elvét a 74 . cikk és 84 . cikk (1) bekezdése értelmében, azt

${ }_{31}$ Clout case 1580. http://www.uncitral.org/clout/clout/data/esp/clout_case_1580_210116.html (2018. 12. 29.). 
a döntést hozta, hogy a kamatszámítás kezdete a számla kiállításának az időpontja lenne (2010. augusztus 30.). Ez feltehetően megegyezik az áru átvételének időpontjával is, tehát konzisztens a 14. számú vélemény álláspontjával (58. cikk alkalmazása). Ugyanakkor érdekes módon a másodfokú bíróság beemelte az érvelésébe a jóhiszemüség elvét az Egyezmény 7. cikk (1) bekezdéséből, és erre hivatkozva módosította a kamatszámítás kezdetét az első fizetési felszólítás dátumára (2012. július 11.). A bíróság ugyanis úgy ítélte meg, hogy a jóhiszemüség elvével nem öszszeegyeztethető az, ha a vevőnek kamatot kéne fizetnie arra a kétéves szünetre vonatkozóan, ami a számla és a fizetési felszólítás között volt.

\section{4. Összefoglalás}

A megvizsgált jogesetek sajnos azt mutatják, hogy még mindig nem egységes az Egyezmény rendelkezéseinek az értelmezése, valamint a Tanácsadó Testület véleményeit sem veszik mindig figyelembe a nemzeti bíróságok, annak ellenére, hogy ezek a vélemények az Egyezmény egységes értelmezése szempontjából fontosak lennének. Ugyanakkor optimizmusra adhat okot, hogy már vannak olyan jogesetek, amelyeknél a bíróság (például a Gerechtshof Den Haag előtti ügyben) vagy valamelyik fél (Nucap Indus. Inc. v. Robert Bosch LLC ügyben) hivatkozik a Tanácsadó Testület véleményére, és azoknak megfelelően értelmezik az Egyezmény egyes rendelkezéseit. Véleményünk szerint, az egységes értelmezés kialakulásához hoszszú időre lesz szükség, ugyanis különböző jogrendszerekről, kultúrákról, nyelvekről van szó. Arról nem is beszélve, hogy az Egyezmény alkalmazhatósága csak nagyon ritkán merül fel egy-egy bíróság előtt (az összes peres ügyhöz viszonyítva), tehát a bíráknak csak kis része találkozik vele a gyakorlatban a pályafutása során. Így nem várható el tőlük, hogy behatóbban tanulmányozzák az Egyezményt és az azzal kapcsolatos tanácsadó testületi véleményeket, szakirodalmat, ami szintén lassítja az egységes értelmezés kialakulását.

\section{Abstract}

Standardisation has a huge importance for economic efficiency in a globalized world. This is also true for legal science, especially for the field of international commercial law. One of the most important international instruments that aims to achieve standardisation is the United Nations Convention on Contracts for the International Sale of Goods or the Vienna Convention. This convention has been ratified by 89 different countries. Due to its application in so many legal systems, it is worth following the interpretations of its provisions in practice by particular national courts, and the opinions of the CISG Advisory Council. The article examines opinions related to the issues of the deadline for the examination of the goods and notice of non-conformity by the buyer (opinion no. 2), inclusion of standard terms under the CISG (opinion no. 13) and interest under article 78 CISG (opinion no. 14). 
